\title{
Swift Foxes and Ideal Free Distribution: Relative Influence of Vegetation and Rodent Prey Base on Swift Fox Survival, Density, and Home Range Size
}

\author{
Craig M. Thompson ${ }^{1,2}$ and Eric M. Gese ${ }^{1,3}$ \\ ${ }^{1}$ Department of Wildland Resources, Utah State University, Logan, UT 84322, USA \\ ${ }^{2}$ Pacific Southwest Research Station, Forest Service, U.S. Department of Agriculture, Fresno, CA 93710, USA \\ ${ }^{3}$ National Wildlife Research Center, Wildlife Services, U.S. Department of Agriculture, Logan, UT 84322, USA
}

Correspondence should be addressed to Eric M. Gese, eric.gese@usu.edu

Received 23 April 2012; Accepted 16 May 2012

Academic Editors: A. Arslan and A. Ramirez-Bautista

Copyright (C) 2012 C. M. Thompson and E. M. Gese. This is an open access article distributed under the Creative Commons Attribution License, which permits unrestricted use, distribution, and reproduction in any medium, provided the original work is properly cited.

\begin{abstract}
Swift foxes (Vulpes velox) are an endemic mesocarnivore of North America subject to resource and predation-based pressures. While swift fox demographics have been documented, there is little information on the importance of top-down versus bottom-up pressures or the effect of landscape heterogeneity. Using a consumable resource-based ideal free distribution model as a conceptual framework, we isolated the effects of resource-based habitat selection on fox population ecology. We hypothesized if swift fox ecology is predominantly resource dependant, distribution, survival, and space use would match predictions made under ideal free distribution theory. We monitored survival and home range use of 47 swift foxes in southeastern Colorado from 2001 to 2004. Annual home range size was $15.4 \mathrm{~km}^{2}$, and seasonal home range size was $10.1 \mathrm{~km}^{2}$. At the individual level, annual home range size was unrelated to survival. Estimates of fox density ranged from 0.03 to 0.18 foxes $/ \mathrm{km}^{2}$. Seasonal survival rates were 0.73 and 1.0 and did not differ seasonally. Foxes conformed to the predictions of the ideal free distribution model during winter, indicating foxes are food stressed and their behavior governed by resource acquisition. During the rest of the year, behavior was not resource driven and was governed by security from intraguild predation.
\end{abstract}

\section{Introduction}

Swift foxes (Vulpes velox) are a mesocarnivore endemic to the Great Plains region of North America. Historically, swift foxes occupied the extensive shortgrass prairie regions from central Canada into New Mexico and Texas and from the Rocky Mountains east into Iowa $[1,2]$. Today, they are found in a variety of landscapes, ranging from shrub steppe to agricultural to ranchland to native shortgrass prairie $[3,4]$. While they are capable of exploiting a wide range of habitats, reported population parameters such as density and survival vary widely indicating variation in habitat quality. There is little information on landscape structure or disturbance thresholds that control swift fox abundance or lead to exclusion [5].

The ideal free distribution [6] has been used to study the influence of predation on prey distribution [7]. According to the tenets of the ideal free distribution, high-quality habitat should be occupied to a certain threshold at which point competition or social structure forces animals into poorerquality areas. In this case, survival and reproductive success would be similar across landscapes though density and home range size would vary. However, most applications of the ideal free distribution to predator-prey interactions have assumed predation risk is constant between habitats $[8,9]$. Predation risk is rarely constant across habitats and patches [10], and extensive work has indicated that under the threat of predation, prey species preferentially forage in "safer" habitats [10-13]. The inclusion of variable predation risk into ideal free distribution models has indicated that prey density is more strongly influenced by the "riskiness" of the habitat than by resource availability [8].

Swift fox population parameters in different landscapes have been well documented [14]; however, there is little 
information available addressing the differences between reported values. In order to begin addressing the effects of landscape structure on swift fox distribution and demographics, we explored the effects of landscape heterogeneity on population parameters likely to reflect habitat quality, such as population density, home range size, and survival. For this paper, we assessed the relative quality of different landscapes as fox habitat based on vegetation structure and prey base using the ideal free distribution theory as a conceptual framework. While the ideal free distribution is limited due to its resource-based approach, it provides a conceptual starting point for investigating the relative importance of resource availability on a native mesocarnivore.

Under the ideal free distribution theory we made the following series of predictions. (1) At the regional level, estimates of swift fox density will vary across landscapes while survival rates will not. (2) At the individual level, swift fox survival rates will be unrelated to home range size. (3) Swift fox home range size will be negatively related to rodent prey base. (4) Swift fox home range size will be related to vegetative structural elements that enhance rodent prey availability. The strength of these relationships or variation from these predictions can indicate the relative importance of resource-based influences on swift fox ecology. To address these predictions, we evaluated swift fox spatial ecology at 4 spatial-temporal scales in southeastern Colorado between 2001 and 2004. Scales included combinations of individual versus population parameters and seasonal versus annual responses. By comparing field data to the predictions made under the ideal free distribution model, we were able to investigate the relative influence of top-down (predation) versus bottom-up (resource/vegetation) factors on swift fox distribution and range use. The study was conducted on and around the US Army Piñon Canyon Maneuver Site where recent, dramatic shifts in the disturbance regime due to military purchase, as well as discrete boundaries, resulted in a locally heterogeneous environment. The spatial scale of our research was small enough to assume that prior to military ownership, the landscape had been fairly homogonous and swift fox population parameters were spatially consistent. The abrupt shift in ownership, the discrete boundaries, and the patterns of land use in the area coalesced into a natural experiment on the effects of landscape structure on a native mesocarnivore.

\section{Materials and Methods}

2.1. Study Site. We conducted research on and around the $1,040 \mathrm{~km}^{2}$ Piñon Canyon Maneuver Site (PCMS) located in Las Animas County, Colorado (Figure 1). North of the PCMS the study area extended into the US Forest Service, Comanche National Grassland. The study area also extended southward onto private ranchlands. The region was classified as semiarid grassland steppe, with approximately $60 \%$ of the PCMS categorized as shortgrass prairie dominated by blue grama (Bouteloua gracilis), western wheatgrass (Agropyron smithii), and galleta (Hilaria jamesii) [15]. Shrublands interspersed throughout the study area included four-winged saltbrush (Atriplex canescens) and greasewood (Sarcobatus vermiculatus), as well as prickly pear cactus (Opuntia phaeacantha), tree cholla (Cylindropuntia imbricata), and yucca (Yucca glauca). The remaining landscape was dominated by pinyon-juniper woodland (Pinus edulis and Juniperus monosperma). Elevation varied between 1,310 and $1,740 \mathrm{~m}$, average temperatures ranged from $1^{\circ} \mathrm{C}$ in January to $23^{\circ} \mathrm{C}$ in July, and precipitation averaged $30 \mathrm{~cm}$ but can fluctuate widely [16]. Monthly precipitation was the highest in July with an average of $4.3 \mathrm{~cm}$ of rain, though the $35 \%$ of the annual precipitation that fell during the cool-season (MarchMay) had a proportionally greater impact on productivity [17].

The maneuver site was purchased by the US Army in 1982 to facilitate large-scale mechanized infantry training activities. Prior to this, both the maneuver site and the surrounding area had been grazed by domestic livestock since the late 1800s [18]. Livestock were excluded in 1983 and training began in 1985 [17]. On the maneuver site, training intensity varied widely simply due to the logistics of maneuvering large, mechanized infantry units. As a result, remnant areas subject to very little disturbance were scattered throughout the base. At the same time, areas surrounding the base continued to be grazed by domestic livestock. This natural heterogeneity provided the basis for our identification of areas with variable vegetation structure.

2.2. Study Design. We established 6 study sites in areas subjected to 3 land use regimes: livestock grazing, mechanized military training, and unused. Unused sites were peripheral portions of the military base that were not used for military training yet were subject to fire suppression and livestock exclusion. Sites were named according to local landmarks or historical owners: Private (PRV), Biernacki's (BTS), Pronghorn (PRN), Red Rocks (RRK), Bent (BNT), and Comanche (COM). Data collection was based on 3 seasons: winter (breeding/gestation: 15 December-14 April), summer (pup-rearing: 15 April-14 August), and fall (dispersal: 15 August-14 December) [18-20]. Between 2001 and 2004, we conducted fox trapping surveys, radio telemetry of collared foxes, small mammal trapping, and vegetation surveys on each site during each season every year.

2.3. Swift Fox Capture and Radiotelemetry. We captured swift foxes using double-door box traps (Tomahawk Live Trap Company, Tomahawk WI) baited with chicken [20, 21]. Traps were placed $500 \mathrm{~m}$ apart along a $10 \mathrm{~km}$ transect bisecting each site resulting in 21 traps per site. Each trap was oriented and covered with brush to provide protection from exposure. Traps were set in the late afternoon, checked early the following morning, and left closed throughout the day. Each transect was trapped for 4 consecutive nights 3 times per year. For recollaring or targeting animals, a trapenclosure system was used at den sites [22]. Captured foxes were handled without anesthesia and weighed, sexed, and aged through tooth wear (adult, juvenile). Foxes were considered juvenile until the pup-rearing season following their 


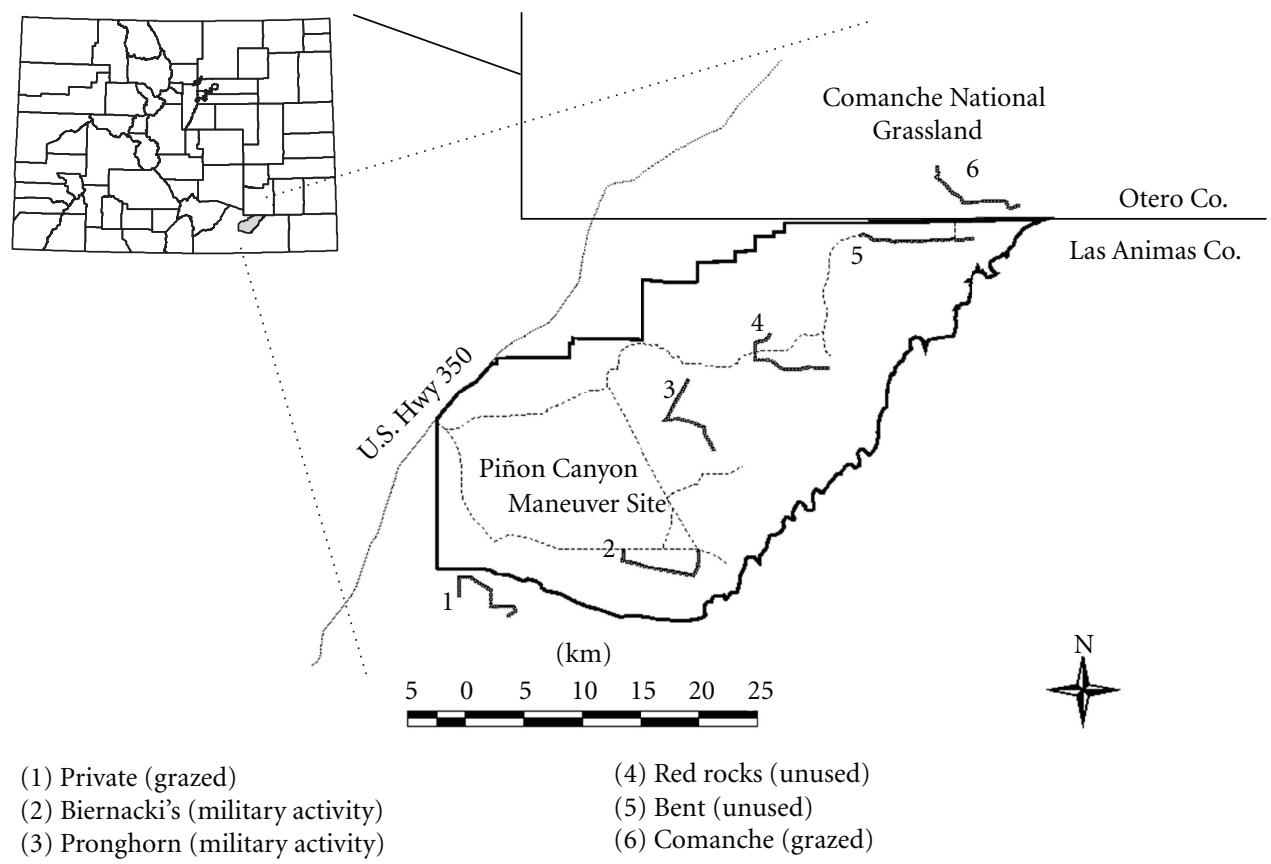

Figure 1: Six study sites on and around the Piñon Canyon Maneuver Site in southeastern Colorado. Locations of 6 transects are indicated, as well as the associated dominant land use for that site.

birth (15 April). Foxes were ear-tagged and collared with 30$50 \mathrm{~g}$ radio transmitters (Advanced Telemetry Systems, Isanti, $\mathrm{MN})$.

We located foxes a minimum of 3 times per week, twice during nighttime hours when animals were actively hunting, and once during daylight hours to locate den sites. Locations were considered independent when separated by at least 4 hours [23], more than sufficient time for a swift fox to cross its home range. Nocturnal locations were estimated using triangulation of 2-3 bearings within 5 minutes and separated by at least $40^{\circ}$. Triangulation was done using Program Locate II (Pacer, Truro, Nova Scotia). Diurnal locations were collected visually by approaching the animal until either a den could be identified or the animal was seen.

2.4. Swift Fox Population Parameters. Swift fox home ranges were calculated at 4 spatiotemporal scales; annual and seasonal ranges at both site and individual levels. All calculated ranges were based on a minimum of 30 locations. Previous area-observation analyses [18] indicated 31 locations were the minimum needed to estimate an individual, unbiased swift fox home range. All ranges used in analyses were based on the 95\% fixed kernel isopleth [24] using a leastsquares cross-validation smoothing parameter. Least-squares cross-validation allows the smoothing parameter $(h)$ to be chosen that minimizes the squared distance between the fitted surface and the target surface by varying the bandwidth [25]. Core use areas (50\% isopleth) were also calculated for comparison between sites. All ranges were calculated using the Animal Movements extension of ArcView GIS 3.3 [26]. In this environment there are no "habitat patches"; quality is a gradient blending from suitable into unsuitable and all home ranges contain elements of each. Therefore, kernel range estimators are more appropriate than minimum convex polygon methods due to the fact that there are areas within ranges that are avoided by residents.

Site-level survival rates, both seasonal and annual, were estimated using the known fate model in Program MARK [27]. Due to our emphasis on established breeding territories, only adult animals were used. Individuals not located during a season were censored for that season. Individual fox survival was calculated as the proportion of either season or year that the fox survived [20]. Proportions were weighted by the number of days they could be monitored after capture. Periods when the animal was not found were censored due to our inability to determine whether the animal was present and missed or had temporarily left the area.

We estimated the number of foxes in each site using the robust model in Program MARK. Seasonal survival estimates were taken from a telemetry-based known fate model due to the greater precision. Dispersal rates were estimated based on the number of radioed animals that abandoned an existing home range. Juvenile animals were considered dispersers if they left the vicinity of their natal territory, whether or not they survived to establish a range. Population estimates were converted into density estimates by calculating the "effective trapping area" associated with each transect [18, 28]. The radius of the average seasonal 95\% kernel home range for each site was used to buffer the transect in ArcView GIS $[18,28]$. The resulting polygon was considered the "effective trapping area" for that site $[18,28]$. Density estimates were consolidated into seasonal averages as well as an overall estimate for each site. 
2.5. Landscape Variables. For each of the 6 study sites, we evaluated vegetation structure based on $50 \times 70 \mathrm{~m}$ sampling grids randomly located $<1 \mathrm{~km}$ of the trapping transect. Four grids were sampled each season, and new grids were selected each subsequent season. Each grid consisted of seven $50 \mathrm{~m}$ line transects oriented north-south and spaced $10 \mathrm{~m}$ apart. On each line transect, vegetation type and height were evaluated by dropping a measuring pin every $1 \mathrm{~m}$ and recording the type and height of the tallest vegetation encountered [29]. For each grid, point measurements were combined into estimates of percent basal cover, percent bare ground, percent litter (dead material), and mean shrub and grass height. Shrub density was calculated by counting all woody plants $>20 \mathrm{~cm}$ high within the grid. Grid estimates were combined into seasonal and annual averages for each study site. Standard deviations of grid estimates for each study site were used to represent the homogeneity of vegetation characteristics across each study site.

Following vegetation sampling, 35 Sherman live traps were placed throughout the grid with $10 \mathrm{~m}$ spacing to evaluate swift fox prey base. Analysis of 659 swift fox scats collected on the PCMS between 1997 and 1998 found small mammals constituted the bulk of the foxes' diet throughout the year [19]. Insects were an ephemeral food resource only during the summer, but rodents were utilized year-round and therefore we concentrated prey sampling on the rodent prey base. Traps were baited with equine sweet feed (corn, oats, and molasses). Trapping grids were run for 4 nights, checked and closed each morning, and reset each afternoon. Captured rodents were marked with Sharpie pens on the tail and abdomen allowing for identification of recaptures over the 4-day trapping period. Species richness was calculated as the number of species captures. Diversity was estimated using the Shannon-Weaver index [30]. Prey biomass was estimated using the species average weight [31] multiplied by the number of individual animals captured.

The Pearson correlation coefficients were used to reduce the number of variables prior to analysis. Final vegetation variables selected were mean grass height, mean shrub height, percent basal cover, shrub density, standard deviation of basal cover, standard deviation shrub height, and standard deviation shrub density. Standard deviation variables were included to represent landscape heterogeneity. Final prey base variables selected included capture rates of the three most common species (Ord's kangaroo rat (Dipodomys ordii), northern grasshopper mouse (Onychomys leucogaster), and deer mouse (Peromyscus maniculatus)), total captures of all species, mean per capita biomass, species richness, and species diversity. The standard deviation of richness and diversity was included as predictor variable to reflect community heterogeneity. Per capita biomass was included because as grassland converts to shrubland, a community shift may sometimes occur where relatively rare, large bodied rodents are replaced by smaller-bodied species with fewer antipredator defenses [32]. All vegetation and prey base variables were log-transformed to improve normality.

We used ANOVA to determine whether density or survival varied between sites. Stepwise multiple regression was used to identify which landscape variables best predicted fox home range size (SAS v.9.2). Independent variables with $P<0.1$ were included in the regression models and tolerance values were set at 0.1 to control for multicollinearity $[33,34]$.

\section{Results}

A total of 47 (24 M : 23 F) individual animals survived long enough and met the minimum number of locations for calculating a seasonal home range at least once (Table 1). For these 47 animals, we calculated 69 temporally independent annual (34 male and 35 female) and 136 temporally independent seasonal (68 male and 68 female) home ranges. Overall the average annual home range size of swift foxes was $15.4 \pm 9.2(\mathrm{SD}) \mathrm{km}^{2}$, and the average seasonal home range size was $10.1 \pm 6.7 \mathrm{~km}^{2}$. The average core use area (50\% kernel isopleth) for swift foxes was $1.2 \pm 1.1 \mathrm{~km}^{2}$. The average seasonal home range and core use area for male foxes were $12.0 \pm 6.9 \mathrm{~km}^{2}$ and $1.5 \pm 1.3 \mathrm{~km}^{2}$, respectively. Female home ranges and core use areas were smaller, averaging $8.1 \pm$ $5.8 \mathrm{~km}^{2}$ and $0.9 \pm 0.8 \mathrm{~km}^{2}$, respectively. Estimated seasonal home ranges in the breeding season were $14.2 \pm 8.2 \mathrm{~km}^{2}$ for male foxes and $7.3 \pm 4.0 \mathrm{~km}^{2}$ for female foxes. During the pup-rearing season, average home ranges were $9.5 \pm 5.6 \mathrm{~km}^{2}$ for male foxes and $6.2 \pm 3.6 \mathrm{~km}^{2}$ for female foxes. During the dispersal season, ranges averaged $12.7 \pm 86.3 \mathrm{~km}^{2}$ and $11.7 \pm 8.0 \mathrm{~km}^{2}$ for males and females, respectively. Home range sizes and sample sizes varied among the six sites (Table 1).

3.1. Prediction 1: At the Regional Level, Swift Fox Densities Will Vary Across Landscapes While Survival Will Not. Swift fox population density estimates (Table 2) differed between sites $(F=7.48, P<0.001)$. Estimates ranged from $0.03 \pm 0.05$ foxes $/ \mathrm{km}^{2}$ on a grazed site (PRV) to $0.18 \pm 0.10$ foxes $/ \mathrm{km}^{2}$ on an unused site (BNT). Seasonal survival rates ranged between 0.73 on a military site to 1.0 on a grazed site and rates did not differ significantly between seasons $(F=0.56$, $P=0.58)$. The Bent site was excluded from this analysis due to small sample size and poor survival estimates.

3.2. Prediction 2: At the Individual Level, Swift Fox Survival Will Be Unrelated to Home Range Size. At the individual level, annual home range size was unrelated to survival $\left(R^{2}=0.03\right.$, $F=2.68, P=0.11)$. Individual-level results do reflect some pseudoreplication as more than one annual range was included for 15 of 47 animals.

3.3. Prediction 3: Swift Fox Home Range Size Will Be Negatively Related to Rodent Prey Base. Between 2001 and 2004, 185 small mammal trapping grids were sampled for a total of 740 grid nights. Individual species capture rates were uncorrelated with each other, but they were correlated with rodent community indices such as diversity or richness. The Pearson correlation coefficients for these comparisons ranged from 0.07 to 0.77 (Table 3 ). These correlations stem from the fact that three species (Ord's kangaroo rat, Northern grasshopper mouse, and deer mouse) accounted for over 
TABle 1: Seasonal home ranges and core use areas for male and female swift foxes in 6 study sites located on and around the Piñon Canyon Maneuver Site, Colorado, 2001-2004. Parentheses indicate sample sizes of foxes that were identical between home range and core use. Total ranges are presented as \pm SE.

\begin{tabular}{|c|c|c|c|c|c|c|c|}
\hline \multirow{2}{*}{ Site } & \multirow{2}{*}{ Sex } & \multicolumn{3}{|c|}{ Home range (95\%) } & \multicolumn{3}{|c|}{ Core use (50\%) } \\
\hline & & Dispersal & Breeding & Pup-rearing & Dispersal & Breeding & Pup-rearing \\
\hline \multirow{2}{*}{ PRV } & $\mathrm{M}$ & $10.46(9)$ & $11.03(2)$ & $6.86(5)$ & 1.56 & 1.12 & 0.86 \\
\hline & $\mathrm{F}$ & $7.55(6)$ & $7.32(5)$ & $4.89(11)$ & 0.75 & 0.64 & 0.72 \\
\hline \multirow{2}{*}{ BTS } & $\mathrm{M}$ & $16.28(5)$ & $16.69(10)$ & $14.04(7)$ & 1.99 & 2.00 & 2.11 \\
\hline & $\mathrm{F}$ & $12.34(4)$ & $9.03(7)$ & $10.39(6)$ & 1.39 & 1.16 & 0.92 \\
\hline \multirow{2}{*}{ PRN } & $\mathrm{M}$ & $15.94(5)$ & $14.71(3)$ & $11.09(5)$ & 1.58 & 1.54 & 1.29 \\
\hline & $\mathrm{F}$ & $17.33(6)$ & $6.65(4)$ & $6.33(6)$ & 1.88 & 0.87 & 0.60 \\
\hline \multirow{2}{*}{ RRK } & $\mathrm{M}$ & $13.14(1)$ & $8.98(1)$ & $6.35(3)$ & 0.78 & 0.56 & 0.75 \\
\hline & $\mathrm{F}$ & $18.03(1)$ & $6.69(1)$ & $6.32(3)$ & 1.82 & 0.62 & 0.68 \\
\hline \multirow{2}{*}{$\mathrm{BNT}$} & $\mathrm{M}$ & - & $31.79(1)^{1}$ & - & - & $4.13^{1}$ & - \\
\hline & $\mathrm{F}$ & 一 & 一 & - & - & - & - \\
\hline \multirow{2}{*}{$\mathrm{COM}$} & $\mathrm{M}$ & $7.65(3)$ & $6.27(4)$ & $4.93(4)$ & 1.03 & 1.19 & 0.60 \\
\hline & $\mathrm{F}$ & $5.64(3)$ & $2.82(2)$ & $2.27(3)$ & 0.49 & 0.40 & 0.24 \\
\hline \multirow{2}{*}{ Total } & $\mathrm{M}$ & $12.63 \pm 2.0$ & $12.23 \pm 1.6$ & $8.36 \pm 1.0$ & $1.47 \pm 0.3$ & $1.53 \pm 0.3$ & $1.04 \pm 0.2$ \\
\hline & $\mathrm{F}$ & $11.40 \pm 1.8$ & $7.54 \pm 1.5$ & $6.48 \pm 0.9$ & $1.19 \pm 0.2$ & $1.01 \pm 0.4$ & $0.66 \pm 0.1$ \\
\hline
\end{tabular}

${ }^{1}$ Throughout the study, only one animal remained and/or survived on the Bent site throughout a full season. This animal was believed a transient, though it met the requirements for calculating a seasonal home range.

TABLE 2: Estimates of population density ( \pm SE) and survival rates ( \pm SE) for adult swift foxes on 6 sites in southeastern Colorado, 2001-2004.

\begin{tabular}{|c|c|c|c|c|c|}
\hline \multirow{2}{*}{ Site } & \multirow{2}{*}{ Density } & \multirow{2}{*}{ Annual survival } & \multicolumn{3}{|c|}{ Seasonal survival rates } \\
\hline & & & Breeding & Pup rearing & Dispersal \\
\hline PRV & $0.18(0.10)$ & 0.54 & $0.81(0.09)$ & $0.83(0.08)$ & $0.81(0.09)$ \\
\hline $\mathrm{COM}$ & $0.04(0.05)$ & 0.92 & $0.92(0.08)$ & $1.0(0.0)$ & $1.0(0.0)$ \\
\hline BTS & $0.11(0.08)$ & 0.54 & $0.84(0.08)$ & $0.78(0.10)$ & $0.82(0.08)$ \\
\hline PRN & $0.09(0.06)$ & 0.54 & $0.73(0.11)$ & $0.94(0.06)$ & $0.79(0.09)$ \\
\hline RRK & $0.05(0.03)$ & 0.50 & $0.80(0.18)$ & $0.83(0.15)$ & $0.75(0.22)$ \\
\hline $\mathrm{BNT}^{1}$ & $0.03(0.05)$ & - & 一 & - & 一 \\
\hline
\end{tabular}

${ }^{1}$ Throughout the study, only one animal remained and/or survived on the Bent site throughout a full season. As a result we were unable to estimate survival rates for that site.

$75 \%$ of all captures and therefore dominated community indices. Despite these correlations, all variables were used in the analysis due to biological importance and interpretive capacity. As stated above, regression tolerance values were adjusted to reduce the effects of these correlations.

Across all spatial-temporal scales, capture rate of Northern grasshopper mice was the variable most consistently associated with swift fox home range size (Table 4). Deer mouse capture rate was the second most common variable, emerging once as the primary and twice as a secondary explanatory variable. While regression models were generally statistically significant, they had low explanatory power with $R^{2}<0.20$. One exception was the relationship between mean population-level breeding season home ranges and Northern grasshopper mice captures $\left(R^{2}=0.467, P=0.02\right)$. Inclusion of community richness raised the $R^{2}$ to 0.65 but raised the $P$ value to 0.08 . Core use areas, both annual and seasonal, were unrelated to prey base variables; controlling for sex had no effect on the analyses.
3.4. Prediction 4: Swift Fox Home Range Size Will Be Related to Vegetative Structural Elements That Enhance Rodent Prey Availability. Vegetation structural measurements were taken on the same 185 grids described above. A number of the measurements were correlated, with the Pearson correlation values ranging from 0.06 to 0.90 (Table 3 ). In particular, percent basal cover and the standard deviation of shrub height were highly correlated $(P<0.05)$ with most other variables. As described above, all variables were included in the analysis due to biological importance and regression tolerance values were adjusted accordingly.

Only one vegetative variable (shrub density) was consistently related to home range size across all spatiotemporal scales (Table 4). In general this relationship explained a low proportion of the variance in home range size with the exception of the population level, breeding season analysis $\left(R^{2}=0.39, P=0.04\right)$. Core use areas, both annual and seasonal, were not significantly related to landscape variables. Controlling for sex had no effect on the analyses. 
TAble 3: The Pearson correlation coefficients for swift fox prey base and vegetation structure variables on 185 sampling grids in southeastern Colorado, 2001-2004. Capture rates indicate the total number of individuals captured for selected species. Total captures, biomass, and community indices include all species. Values exceeding \pm 0.34 are significant at the $P=0.05$ level.

\begin{tabular}{|c|c|c|c|c|c|c|c|c|c|}
\hline Prey base variables & $\begin{array}{c}\text { Ord's } \\
\text { kangaroo rat }\end{array}$ & $\begin{array}{l}\text { N. grasshopper } \\
\text { mouse }\end{array}$ & Deer mouse & Total captures & $\begin{array}{c}\text { Per capita } \\
\text { biomass }\end{array}$ & Richness & Diversity & $\begin{array}{c}\mathrm{SD} \\
\text { richness } \\
\end{array}$ & $\begin{array}{c}\mathrm{SD} \\
\text { diversity }\end{array}$ \\
\hline Ord's kangaroo rat & - & 0.26 & 0.46 & 0.57 & 0.53 & 0.55 & 0.62 & 0.55 & 0.73 \\
\hline $\begin{array}{l}\text { N. grasshopper } \\
\text { mouse }\end{array}$ & & - & 0.18 & 0.50 & 0.37 & 0.50 & 0.30 & 0.48 & -0.18 \\
\hline Deer mouse & & & - & 0.46 & 0.32 & 0.44 & 0.50 & 0.53 & 0.41 \\
\hline Total captures & & & & - & 0.59 & 0.99 & 0.71 & 0.72 & 0.48 \\
\hline Per capita biomass & & & & & - & 0.58 & 0.41 & 0.46 & 0.32 \\
\hline Richness & & & & & & - & 0.83 & 0.73 & 0.56 \\
\hline Diversity & & & & & & & - & 0.72 & 0.82 \\
\hline SD richness & & & & & & & & - & 0.67 \\
\hline SD diversity & & & & & & & & & - \\
\hline $\begin{array}{l}\text { Vegetation structure } \\
\text { variables }\end{array}$ & $\%$ basal area & $\begin{array}{c}\text { Mean grass } \\
\text { height }\end{array}$ & $\begin{array}{c}\text { Mean shrub } \\
\text { height }\end{array}$ & Shrubs/100 $\mathrm{m}^{2}$ & $\begin{array}{c}\text { SD basal } \\
\text { area }\end{array}$ & $\begin{array}{l}\text { SD shrub } \\
\text { height }\end{array}$ & \multicolumn{3}{|c|}{$\mathrm{SD}$ shrubs/100 m² } \\
\hline$\%$ basal cover & - & 0.43 & 0.46 & 0.30 & 0.11 & 0.41 & \multicolumn{3}{|c|}{0.23} \\
\hline Mean grass height & & - & 0.76 & 0.39 & 0.31 & 0.20 & \multicolumn{3}{|c|}{0.20} \\
\hline Mean shrub height & & & - & 0.65 & 0.26 & 0.88 & \multicolumn{3}{|c|}{0.52} \\
\hline Shrubs $/ 100 \mathrm{~m}^{2}$ & & & & - & 0.06 & 0.39 & \multicolumn{3}{|c|}{0.90} \\
\hline SD basal area & & & & & - & 0.26 & \multicolumn{3}{|c|}{0.15} \\
\hline SD shrub height & & & & & & - & \multicolumn{3}{|c|}{0.35} \\
\hline SD shrubs/100 m² & & & & & & & \multicolumn{3}{|c|}{-} \\
\hline
\end{tabular}

TABLE 4: Results of stepwise regression analysis of (a) vegetation structure variables and (b) prey base variables against home range size for swift foxes in southeastern Colorado, 2001-2004. Italics indicate a negative relationship.

(a)

\begin{tabular}{|c|c|c|c|c|c|c|c|}
\hline Spatial scale & Temporal scale & Primary variable & $\begin{array}{c}\text { Partial } \\
R^{2}\end{array}$ & Secondary variable & Partial $R^{2}$ & Model $R^{2}$ & Model $F$ \\
\hline \multirow{4}{*}{ Individual } & Annual & Shrub density & 0.044 & None & & 0.044 & 0.085 \\
\hline & Dispersal & SD (\% basal area) & 0.121 & None & & 0.121 & 0.040 \\
\hline & Pup-rearing & $\mathrm{SD}$ (mean shrub ht) & 0.142 & None & & 0.142 & 0.028 \\
\hline & Breeding & SD (mean shrub ht) & 0.284 & None & & 0.284 & 0.002 \\
\hline \multirow{4}{*}{ Population } & Annual & Shrub density & 0.172 & Mean grass ht & 0.129 & 0.301 & 0.025 \\
\hline & Dispersal & (no variables entered the model) & & & & & \\
\hline & Pup-rearing & (no variables entered the model) & & & & & \\
\hline & Breeding & Shrub density & 0.393 & None & & 0.393 & 0.039 \\
\hline
\end{tabular}

(b)

\begin{tabular}{|c|c|c|c|c|c|c|c|}
\hline $\begin{array}{l}\text { Spatial } \\
\text { scale }\end{array}$ & Temporal scale & $\begin{array}{l}\text { Primary } \\
\text { variable }\end{array}$ & $\begin{array}{c}\text { Partial } \\
R^{2} \\
\end{array}$ & Secondary variable & Partial $R^{2}$ & Model $R^{2}$ & Model $P$ \\
\hline \multirow{4}{*}{ Individual } & Annual & N. grasshopper mouse captures & 0.086 & Deer mouse captures & 0.052 & 0.137 & 0.056 \\
\hline & Dispersal & N. grasshopper mouse captures & 0.143 & Deer mouse captures & 0.138 & 0.281 & 0.025 \\
\hline & Pup-rearing & Mean per capita biomass & 0.107 & None & & 0.107 & 0.068 \\
\hline & Breeding & deer mouse captures & 0.181 & None & & 0.181 & 0.043 \\
\hline \multirow{4}{*}{ Population } & Annual & N. grasshopper mouse capture & 0.105 & Total captures & 0.264 & 0.369 & 0.001 \\
\hline & Dispersal & (no variables entered the model) & & & & & \\
\hline & Pup-rearing & (no variables entered the model) & & & & & \\
\hline & Breeding & N. grasshopper mouse captures & 0.467 & Community richness & 0.179 & 0.646 & 0.078 \\
\hline
\end{tabular}




\section{Discussion}

Currently, there are a number of gaps in our understanding of swift fox ecology, including the influence of landscape variation on local density and demographics. Fundamental to this understanding is the need to quantify the influence of resource limitation versus predation pressure to better understand the processes influencing swift fox density. While they may be capable of exploiting a wide range of landscapes, swift foxes appear to be sensitive to thresholds in vegetation structure, prey availability, or predator density beyond which they are excluded. While the ideal free distribution model is limited in its applicability to mesocarnivores, it is a convenient point at which to start investigating the relative importance of bottom-up forces.

Our results indicated swift foxes conform to 2 of the 4 predictions we made under the ideal free distribution theory year-round but conform to the remaining 2 only during the winter breeding season. As the ideal free distribution is a resource-based model, it follows that swift foxes are only resource (food) limited during the winter months. During the remaining two-thirds of the year fox home range placement reflected other pressures, most likely avoidance of intraguild predation by coyotes $[5,35]$. This pattern appears to reflect what has been termed an "adaptive compromise" [11]; during periods of food stress swift foxes may trade security for enhanced resource availability. Similar behavior has been well documented in aquatic systems and with invertebrates, birds, and mammals; see [10] for a review.

The idea that swift foxes make this adaptive compromise during winter months is supported by two additional lines of evidence. First, several studies have reported that winter months are the most resource poor for swift foxes $[5,14,36]$. In our study, $68 \%$ of small mammal captures occurred during summer months (April 15-August 15). Twenty-three percent of captures occurred in winter months and $9 \%$ in fall months. The scarcity of mammalian prey in the fall is offset by increases in insect abundance; insects made up nearly $80 \%$ of the diet of swift foxes during fall months [19]. While mammalian prey becomes important again during winter months [19], a significant portion of this could be scavenged carrion [37]. These results support the idea that during winter months swift foxes may alter their behavior in search of additional food. Second, both our results and a previous study [18] suggest that the predation rate of adult swift foxes by coyotes on the PCMS is the highest in winter months. While the results were not statistically significant, the pattern is consistent over 5 years. This supports the idea that during winter months foxes are more exposed to predation risk.

Swift foxes have the potential to persist in a range of environments, from agricultural to prairie remnants to ranchland [3, 4]. However, survival, density, and home range estimates vary widely [5]. Interpretation of our results suggests that swift fox behavior is a complex balance of seasonal food availability and avoidance of intraguild predation. Earlier work indicated that swift fox density was significantly negatively related to grass height [35], supporting the idea that swift foxes avoid areas of dense vegetation where they are more susceptible to coyote predation due to visual obscurity
[38]. Other studies have indicated many of the primary prey items of swift foxes are found in areas of increased landscape heterogeneity $[30,39]$. Therefore, while low shrub density areas may be high-quality, "safe" habitat during most of the year, swift foxes in these areas may need to expand their ranges into riskier habitat during winter months to meet resource requirements despite the increased risk of predation. At the same time, areas of moderate to high shrub density may provide for energetic requirements year round, but the increased risk of predation makes them less desirable during spring, summer, and fall months. Our results indicate that the highest-quality swift fox habitats are heterogeneous landscapes where resident animals can spend the majority of the year in areas of low risk but have access to riskier, resource-rich patches during winter months. Over the past century, reductions in the complexity of grassland disturbance regimes due to fire suppression and livestock husbandry have led to a homogenization of the landscape, reducing swift foxes' ability to effectively balance resource needs and predation risk.

\section{Acknowledgments}

Funding and logistical assistance was provided by the US Army, Directorate of Environmental Compliance and Management, Fort Carson, Colorado, through the US Fish and Wildlife Service, Colorado Assistance Office, Denver, Colorado, and the US Geological Survey, Utah Cooperative Fish and Wildlife Research Unit at Utah State University, Logan, Utah. Additional support was provided by the US Department of Agriculture, Wildlife Services, National Wildlife Research Center at Utah State University, Logan, Utah. The authors thank T. Warren, B. Rosenlund, M. Klavetter, G. Belew, R. Bunn, and D. Sharps for logistical assistance and E. Joyce, J. White, E. Cleere, M. Watkins, D. Degeranno, A. Larkins, C. Roemer, D. Fletcher, W. Ulrey, S. Schopman, C. Gazal, A. Knipps, J. Garner, and C. Briggs for field assistance. They thank M. Conner, M. Ernst, J. MacMahon, and F. Provenza for reviews of the paper. Research protocols were approved by the Institutional Animal Care and Use Committees at the National Wildlife Research Center and Utah State University.

\section{References}

[1] J. M. Scott-Brown, S. Herrero, and J. Reynolds, "Swift fox," in Wild Furbearer Management and Conservation in North America, M. Novak, J. A. Baker, M. E. Obbard, and B. Malloch, Eds., pp. 433-441, Ontario Trappers Association North Bay, Ontario, Canada, 1987.

[2] FaunaWest, An Ecological and Taxonomic Review of the Swift Fox (Vulpes velox) with Special Reference to Montana, FaunaWest Wildlife Consultants, Boulder, Mont, USA, 1991.

[3] V. L. Jackson and J. R. Choate, "Dens and den sites of the swift fox, Vulpes velox," Southwestern Naturalist, vol. 45, no. 2, pp. 212-220, 2000.

[4] R. S. Matlack, P. S. Gipson, and D. W. Kaufman, "The swift fox in rangeland and cropland in western Kansas: relative abundance, mortality, and body size," Southwestern Naturalist, vol. 45 , no. 2 , pp. 221-225, 2000. 
[5] A. Moehrenschlager, B. L. Cypher, K. Ralls, R. List, and M. A. Sovada, "Swift and kit foxes," in Biology and Conservation of Wild Canids, D. W. Macdonald and C. Sillero-Zubiri, Eds., pp. 185-198, Oxford University, Oxford, UK, 2004.

[6] S. D. Fretwell and H. L. Lucas, "On territorial behavior and other factors influencing habitat distribution in birds-I. Theoretical development," Acta Biotheoretica, vol. 19, no. 1, pp. 16-36, 1969.

[7] M. R. Heithaus, "Habitat selection by predators and prey in communities with asymmetrical intraguild predation," Oikos, vol. 92, no. 3, pp. 542-554, 2001.

[8] D. M. Hugie and L. M. Dill, "Fish and game: a game theoretic approach to habitat selection by predators and prey," Journal of Fish Biology, vol. 45, supplement A, pp. 151-169, 1994.

[9] B. Luttbeg and A. Sih, "Predator and prey habitat selection games: the effects of how prey balance foraging and predation risk," Israel Journal of Zoology, vol. 50, no. 2-3, pp. 233-254, 2004.

[10] S. L. Lima and L. M. Dill, "Behavioral decisions made under the risk of predation: a review and prospectus," Canadian Journal of Zoology, vol. 68, no. 4, pp. 619-640, 1990.

[11] A. Sih, "Optimal behavior: can foragers balance two conflicting demands?" Science, vol. 210, no. 4473, pp. 1041-1043, 1980.

[12] S. E. Hampton, "Habitat overlap of enemies: temporal patterns and the role of spatial complexity," Oecologia, vol. 138, no. 3, pp. 475-484, 2004.

[13] B. P. Kotler, J. S. Brown, A. Bouskila, S. Mukherjee, and T. Goldberg, "Foraging games between gerbils and their predators: seasonal changes in schedules of activity and apprehension," Israel Journal of Zoology, vol. 50, no. 2-3, pp. 255-271, 2004.

[14] M. A. Sovada and L. Carbyn, Ecology and Conservation of Swift Foxes in a Changing World, Canadian Plains Research Center, University of Regina, Saskatchewan, Canada, 2003.

[15] R. B. Shaw, S. L. Anderson, K. A. Schulz, and V. E. Diersing, Plant Communities, Ecological Checklist, and Species List for the U.S. Army Pinon Canyon Maneuver Site, Colorado, Colorado State University Science Series 37, Fort Collins, Colo, USA, 1989.

[16] R. B. Shaw and V. E. Diersing, "Tracked vehicle impacts on vegetation at the Piñon Canyon Maneuver Site, Colorado," Journal of Environmental Quality, vol. 19, no. 2, pp. 234-243, 1990.

[17] D. G. Milchunas, K. A. Schulz, and R. B. Shaw, "Plant community responses to disturbance by mechanized military maneuvers," Journal of Environmental Quality, vol. 28, no. 5, pp. 1533-1547, 1999.

[18] E. R. Schauster, E. M. Gese, and A. M. Kitchen, "Population ecology of swift foxes (Vulpes velox) in southeastern Colorado," Canadian Journal of Zoology, vol. 80, no. 2, pp. 307-319, 2002.

[19] A. M. Kitchen, E. M. Gese, and E. R. Schauster, "Resource partitioning between coyotes and swift foxes: space, time, and diet," Canadian Journal of Zoology, vol. 77, no. 10, pp. 16451656, 1999.

[20] S. M. Karki, E. M. Gese, and M. L. Klavetter, "Effects of coyote population reduction on swift fox demographics in southeastern Colorado," Journal of Wildlife Management, vol. 71, no. 8, pp. 2707-2718, 2007.

[21] D. F. Covell, Ecology of the swift fox (Vulpes velox) in southeastern Colorado [M.S. thesis], University of Wisconsin, Madison, Wis, USA, 1992.

[22] A. J. Kozlowski, T. J. Bennett, E. M. Gese, and W. M. Arjo, "Live capture of denning mammals using an improved box-trap enclosure: kit foxes as a test case," Wildlife Society Bulletin, vol. 31, no. 3, pp. 630-633, 2003.

[23] R. K. Swihart and N. A. Slade, "Influence of sampling interval on estimates of home-range size.," Journal of Wildlife Management, vol. 49, no. 4, pp. 1019-1025, 1985.

[24] B. J. Worton, "Kernel methods for estimating the utilization distribution in home- range studies," Ecology, vol. 70, no. 1, pp. 164-168, 1989.

[25] G. Hemson, P. Johnson, A. South, R. Kenward, R. Ripley, and D. Mcdonald, "Are kernels the mustard? Data from global positioning system (GPS) collars suggests problems for kernel home-range analyses with least-squares crossvalidation," Journal of Animal Ecology, vol. 74, no. 3, pp. 455$463,2005$.

[26] P. N. Hooge and B. Eichenlaub, Animal Movement Extension to ArcView, Version 1.1, Alaska Biological Science Center, U.S. Geological Survey, Anchorage, Alaska, USA, 1997.

[27] G. C. White and K. P. Burnham, "Program MARK: survival estimation from populations of marked animals," Bird Study, vol. 46, supplement, pp. S120-S139, 1999.

[28] E. R. Schauster, E. M. Gese, and A. M. Kitchen, "An evaluation of survey methods for monitoring swift fox abundance," Wildlife Society Bulletin, vol. 30, no. 2, pp. 464-477, 2002.

[29] M. R. Dale, Spatial Pattern Analysis in Plant Ecology, Cambridge University, Cambridge, UK, 1999.

[30] P. J. Morin, Community Ecology, Blackwell Science, Malden, Mass, USA, 1999.

[31] J. O. Whitaker, National Audubon Society Field Guide to North American Mammals, Alfred A. Knopf, New York, NY, USA, 1994.

[32] E. P. White, S. K. Ernest, and K. M. Thibault, "Trade-offs in community properties through time in a desert rodent community," American Naturalist, vol. 164, no. 5, pp. 670-676, 2004.

[33] B. G. Tabachnick and L. S. Fidell, Using Multivariate Statistics, Harper Collins College, New York, NY, USA, 3rd edition, 1996.

[34] K. R. Crooks, "Relative sensitivities of mammalian carnivores to habitat fragmentation," Conservation Biology, vol. 16, no. 2, pp. 488-502, 2002.

[35] C. M. Thompson and E. M. Gese, "Food webs and intraguild predation: community interactions of a native mesocarnivore," Ecology, vol. 88, no. 2, pp. 334-346, 2007.

[36] T. L. Olson and F. G. Lindzey, "Swift fox (Vulpes velox) home-range dispersion patterns in southeastern Wyoming," Canadian Journal of Zoology, vol. 80, no. 11, pp. 2024-2029, 2002.

[37] D. M. Zumbaugh and J. R. Choate, "Winter food habits of the swift fox on the central high plains," Prairie Naturalist, vol. 17, pp. 41-47, 1985.

[38] J. F. Kamler, W. B. Ballard, E. B. Fish, P. R. Lemons, K. Mote, and C. C. Perchellet, "Habitat use, home ranges, and survival of swift foxes in a fragmented landscape: conservation implications," Journal of Mammalogy, vol. 84, no. 3, pp. 989995, 2003.

[39] W. S. Longland and M. V. Price, "Direct observations of owls and heteromyid rodents: can predation risk explain microhabitat use?" Ecology, vol. 72, no. 6, pp. 2261-2273, 1991. 

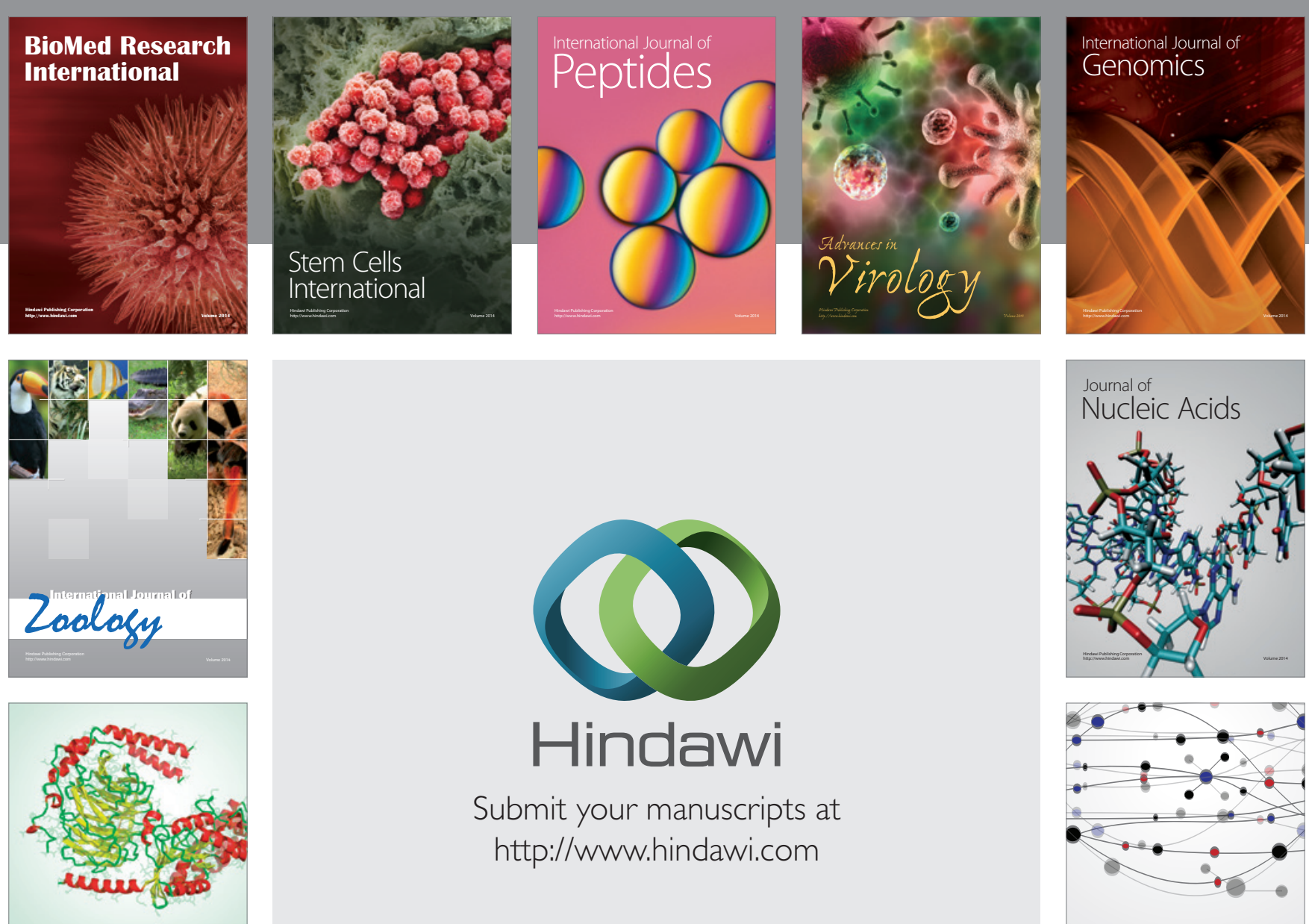

Submit your manuscripts at

http://www.hindawi.com

Signal ${ }^{\text {Jumal }}$ Transduction
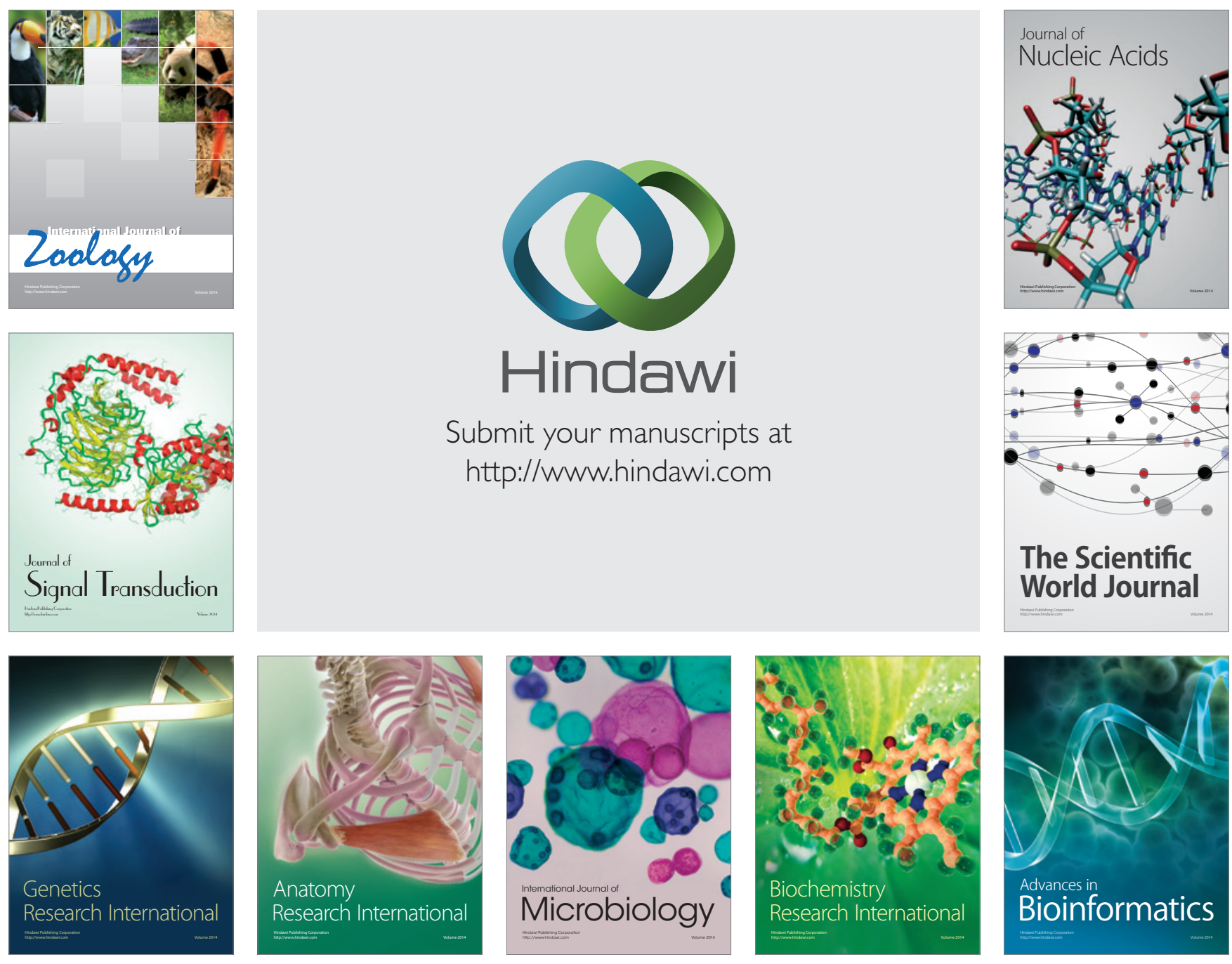

The Scientific World Journal
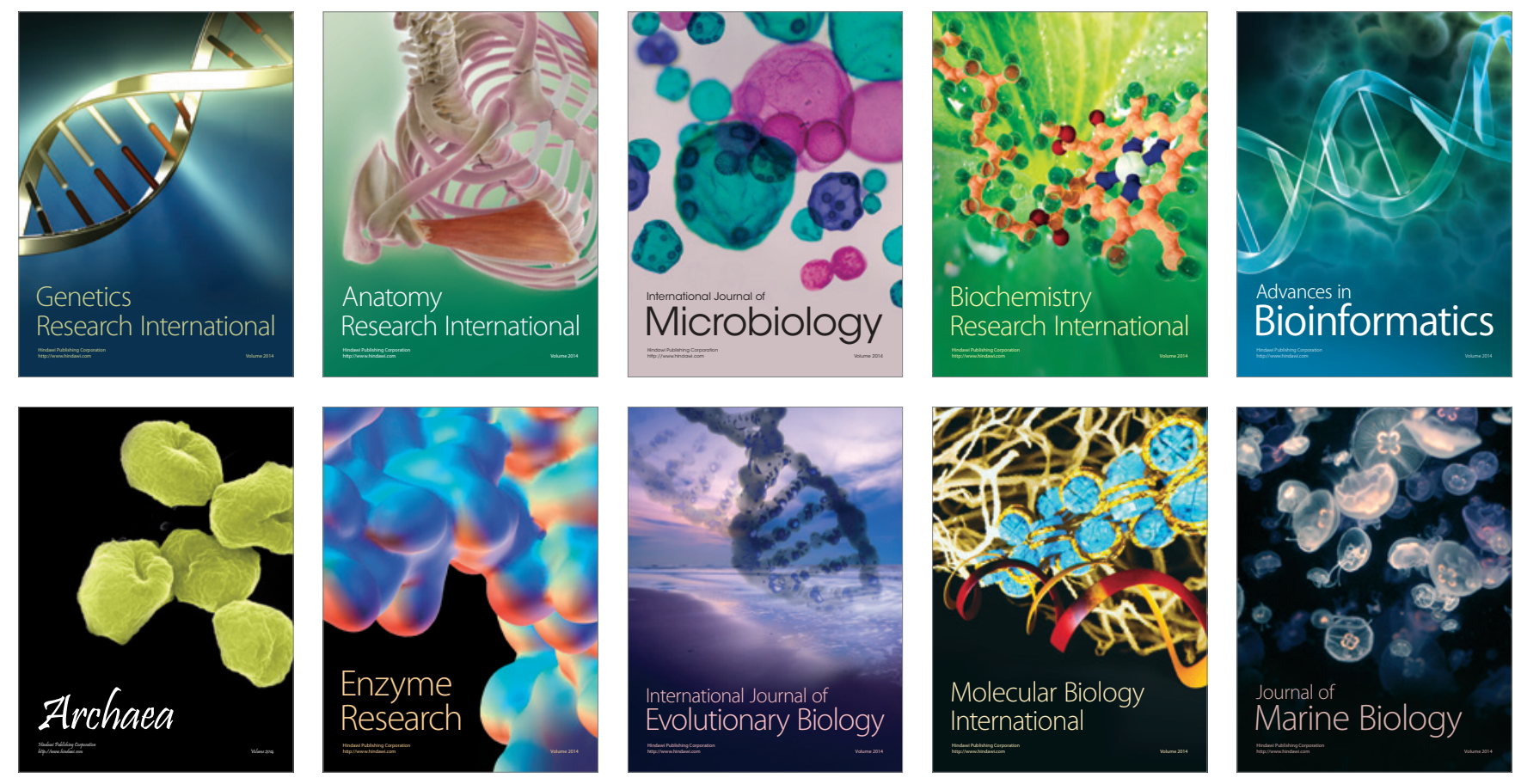